DOI: 10.17707/AgricultForest.64.1.18

\author{
Vera POPOVIĆ, Ljubiša KOLARIĆ, \\ Ljubiša ŽIVANOVIĆ, Jela IKANOVIĆ, \\ Vera RAJIČIĆ, Gordana DOZET, Petar STEVANOVIĆ ${ }^{1}$
}

\title{
INFLUENCE OF ROW SPACING ON NAR-NET PHOTOSYNTHESIS PRODUCTIVITY OF Glycine max (L.) Merrill
}

\begin{abstract}
SUMMARY
Soybean (Glycine max (L.) Merrill) is important legume which is used for humans diet and animal feeding. Beside the significance of certain agro-technical measures (choice of variety, sowing techniques), some physiological indicators, such as the net production of photosynthesis (NAR), are also important for yields achieving and evaluating. The study of the row spacing effects (20, 45 and 70 $\mathrm{cm}$ ) on the productivity of photosynthesis of soybean varieties (Bosa, Balkan and Dragana) were carried out on the soil type of chernozem. The tendency of growth of surface area and number of leaves per plant was recorded up to the fourth measurement in the Bosa and Balkan varieties and until the fifth measurement in the Dragana variety, when the seed formation phase (R5) was established. The highest NAR was observed in early stages of growth, 10-25 days after emergence, while decreasing in later stages. The highest values of NAR in both examined years were recorded at square sowing $(20 \mathrm{~cm})$.
\end{abstract}

Keywords: soybean, variety, row spacing, productivity of photosynthesis

\section{INTRODUCTION}

Soybean - Glycine max (L.) Merrill is important legume which is used in Serbia because of its high yield, good quality of grain. The climate has a major effect upon plant growth and development, and often represents a limiting production factor. Soybean's importance comes first and foremost from the chemical composition of its grain, which is about $40 \%$ protein and around $20 \%$ oil. Because soybeans can be used whole or can be processed to obtain oil or protein, the plant is used widely and extensively not only in the food sector but in various other industries as well. Soybean meal is an indispensable source of protein in the nutrition of livestock, poultry and fish. We must not forget the role of soybean in field crop production either. Being a legume, soybean has the ability to fix atmospheric nitrogen and provide itself with sufficient amounts of

\footnotetext{
${ }^{1}$ Vera M. Popović, (corresponding author: vera.popovic@nsseme.com), Institute of Field and Vegetable Crops, Maksima Gorkog 30, Novi Sad, SERBIA; Ljubiša Kolarić, Ljubiša Živanović, Jela Ikanović, University of Belgrade, Faculty of Agriculture, Nemanjina 6, Zemun Belgrade, SERBIA; Gordana Dozet, Megatrend University, Faculty of Biofarming, Bačka Topola, SERBIA; Vera Rajičić, Center for Small Grain, Kragujevac, SERBIA; Petar Stevanović, Inspection Affairs Administration of Republika Srpska, Banja Luka, BOSNIA AND HERZEGOVINA;

Notes: The authors declare that they have no conflicts of interest. Authorship Form signed online.
} 
readily available nitrogen, thus reducing the need for nitrogen fertilizer application. Leguminous plants, including soybean, are capable to form root nodules in symbiosis with bacteria of Rhizobium and Bradyrhizobium genera, and during that process they convert inorganic nitrogen $\left(\mathrm{N}_{2}\right)$ into ammonium ions $\left(\mathrm{NH}_{4}{ }^{+}\right)$available to the plant. Bradyrhizobium japonicum has a symbiotic relationship with legumes, or more specifically soybean plants. This makes this plant a very good fit for crop rotations (Hrustić et al., 1998; Simić and Vučković, 2014; Terzić et al., 2016; 2017; Kresović et al., 2016; Popović et al., 2013a; 2015; 2016). The introduction of new practices for increasing the seasonal productivity and forage quality of temporary swards by annual legume requires studies on plant material of different origin (Vasileva and Vasilev, 2012; Naydenova et al., 2014; Bozhanska et al., 2016).

Soybean is one of the most significant protein-oil plants. Beside the significance of certain agro-technical measures (such as sowing methods, the choice variety, plot, etc.) some physiological indicators, such as the Net Production of Photosynthesis (NAR), are also important for yields achieving and evaluating. The influence of these physiological indicators on yield and quality of soybean grain is different, according to results of numerous researchers.

A high and stable soybean yield can be achieved only when it is based on the cultivation of varieties of high genetic yield potential with the application of intensive agro-technology. Producers of soybeans in our country have a wide range of domestic varieties that are highly yielding, not genetically modified (Popović, 2010) and adapted to our climate.

One of the conditions for achieving high and stable yields is the proper arrangement of plants at appropriate crop densities. It is known that the square shape is an ideal vegetation space. However, in practice, it is difficult to achieve the shape of a square if soybean is sown at an intermediate distance of $50 \mathrm{~cm}$ and a distance of $3-5 \mathrm{~cm}$.

By changing the shape of the vegetation space, ie. the intermediate distance, the microclimatic conditions of growth soybean plants is changes. Soybean plants is very sensitive with change of the microclimatic conditions, especially in the flowering stage. The shape of vegetation or sowing method has been studied in almost all areas of soybean cultivation. When sowing at a larger interstitial distance, much of the sunlight falls between rows and remains unused, especially in the early part of the soybean vegetation period (Kolarić, 2010). According to many studies, the applied crop density is the prerequisite for expressing the maximum genetic potential for the yield of these varieties (Bullock et al., 1998; Bowers et al., 2000; Holshouser and Whittaker; 2002; Heatherly et al., 2002; Nenadić et al., 2003; Vignjevic, 2006; Popović, 2016a).

The aim of this research is to study the influence of the size of the interstitial spacing at the same density of crops on the productivity of soybean photosynthesis. Based on the results it will be given recommendation for modern soybean technology. 


\section{MATERIAL AND METHODS}

Research was carried out on the test-field in Zemun Polje, on the bad carbonate chernozem soil type, in period of two year. Micro-test was set up as a two-factor, split-plot method in four repetitions. The factors were: row spacing (A) (20, 45 and $70 \mathrm{~cm}$ ) and variety (B): Bosa (0 maturity group), Balkan (I maturity group), Novi Sad; Dragana (II maturity group).

The density of crops within the variety was the same for all varieties and amounted to 500,000 plants per hectare for the Bosa, 450,000 plants per hectare for the Balkan variety and 400,000 plants per hectare for the Dragana variety. The size of calculated sample parcels was $5.4 \mathrm{~m}^{2}(6.0 \times 0.9 \mathrm{~m})$ for a combination of sowing at $45 \mathrm{~cm}$ between rows, $6.0 \mathrm{~m}^{2}(6.0 \times 1.0 \mathrm{~m})$ for a variation of sowing at $20 \mathrm{~cm}$ between rows and $8.4 \mathrm{~m}^{2}(6.0 \times 1.4 \mathrm{~m})$ for planting at $70 \mathrm{~cm}$ spacing between rows, Kolarić et al., 2014a; 2014b. In the experiments, standard agrotechnology for the production of soybean was applied, excluding studied factors. The soybean pre-crop, in both years of research, was corn. Deep plowing $(25 \mathrm{~cm})$ was done in the autumn immediately after maize harvesting, and on that occasion, $100 \mathrm{~kg} \mathrm{ha}^{-1}$ UREA (46\% N) was applied. Early ground preparation was carried out in the spring with seeders. Sowing was done on April $23^{\text {th }}$ in the first examined year and on May 5th in the second examined year. The seed is directly inoculated with the microbiological preparation NS-Nitragin immediately prior to sowing. During the vegetation period, weed weeding and hoeing takes place on two occasions. Harvest was done manually on September 10th in the first and September $17^{\text {th }}$ in the second examined year. During the vegetation period, the photosynthesis productivity was monitored starting from the phase of the first permanent leaves on the stalk until the beginning of the ripening of pods. These measurements were performed every 10 days by taking samples of 5 plants from each accounting plot and from all repetitions.

The surface of the samples was determined by measuring the maximum length and width of the leaves and multiplying with the correction factor 0.72 (Sarić et al., 1986). Based on surface area parameters, fresh and dry matter, NAR (net assimilation rate, net assimilation) was calculated:

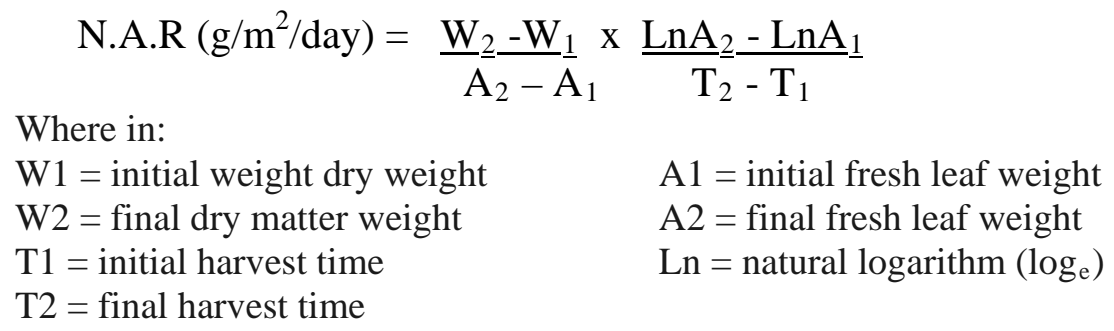

\section{Soil Conditions}

According to the pedological study of the soil in Zemun Polje, carbon chernozem is characterized by humus -accumulative (Ah) horizon of 0-50 cm of depth, dark block color and powdery clay agril texture (Šarčević-Todosijević et 
al., 2016). Study area was conducted two year period in Zemun Polje, (latitude: $44^{\circ} 52^{\prime} 00^{\prime \prime} \mathrm{N}$ and longitude: $20^{\circ} 19^{\prime} 00^{\prime \prime} \mathrm{E}$ ) region of Serbia on the chernozem soil type $(\mathrm{pH}=7.95)$.

Table 1. Chemical properties of soil, Zemun Polje, Serbia

\begin{tabular}{|c|c|c|c|c|c|c|c|c|c|c|c|}
\hline \multirow{2}{*}{$\begin{array}{l}\text { Depth } \\
\text { (cm) }\end{array}$} & \multicolumn{2}{|c|}{$\mathrm{pH}$ in } & \multirow{2}{*}{$\begin{array}{c}\mathrm{CaCO}_{3} \\
\text { (\%) }\end{array}$} & \multirow{2}{*}{$\begin{array}{c}\text { Humus } \\
(\%)\end{array}$} & \multirow{2}{*}{$\begin{array}{l}\text { Total } \\
N(\%)\end{array}$} & \multirow{2}{*}{$\mathrm{C} / \mathrm{N}$} & \multicolumn{3}{|c|}{ Accessible $N(\mathrm{ppm})$} & \multicolumn{2}{|c|}{ mg/100gr soil } \\
\hline & $\mathrm{H}_{2} \mathrm{O}$ & $\mathrm{KCl}$ & & & & & $\mathrm{NH}_{4}$ & $\mathrm{NO}_{3}$ & $\mathrm{NH}_{4}+\mathrm{NO}_{3}$ & $\mathrm{P}_{2} \mathrm{O}_{5}$ & $\mathrm{~K}_{2} \mathrm{O}$ \\
\hline $0-20$ & 7.95 & 7.25 & 1.6 & 2.87 & 0.180 & 9.2:1 & 8.4 & 15.4 & 23.8 & 26.8 & 25.4 \\
\hline $20-40$ & 8.00 & 7.40 & 2.2 & 2.72 & 0.175 & 9.0:1 & 4.9 & 16.8 & 21.7 & 26.8 & 24.3 \\
\hline
\end{tabular}

The soil was neutral to weak alkaline reaction, well provided by total nitrogen and humus, poorly carbonate and with an increased content of $\mathrm{P}_{2} \mathrm{O}_{5}$ and $\mathrm{K}_{2} \mathrm{O}$ (Tab. 1).

\section{RESULTS AND DISCUSSION \\ Meteorological conditions}

Meteorological data were obtained from the Meteorological Station, Zemun Polje, Serbia (Figure 1). Weather conditions are variable and unpredictable (Popović et al., 2013a; 2013b; 2014; 2015; 2016b; Kolarić et al., 2015a; 2015b; Mandić et al., 2016). In first year, about $2^{\circ} \mathrm{C}$ higher air temperatures were recorded, compared to second year, where temperatures were at the level of perennial averages (Figure 1).

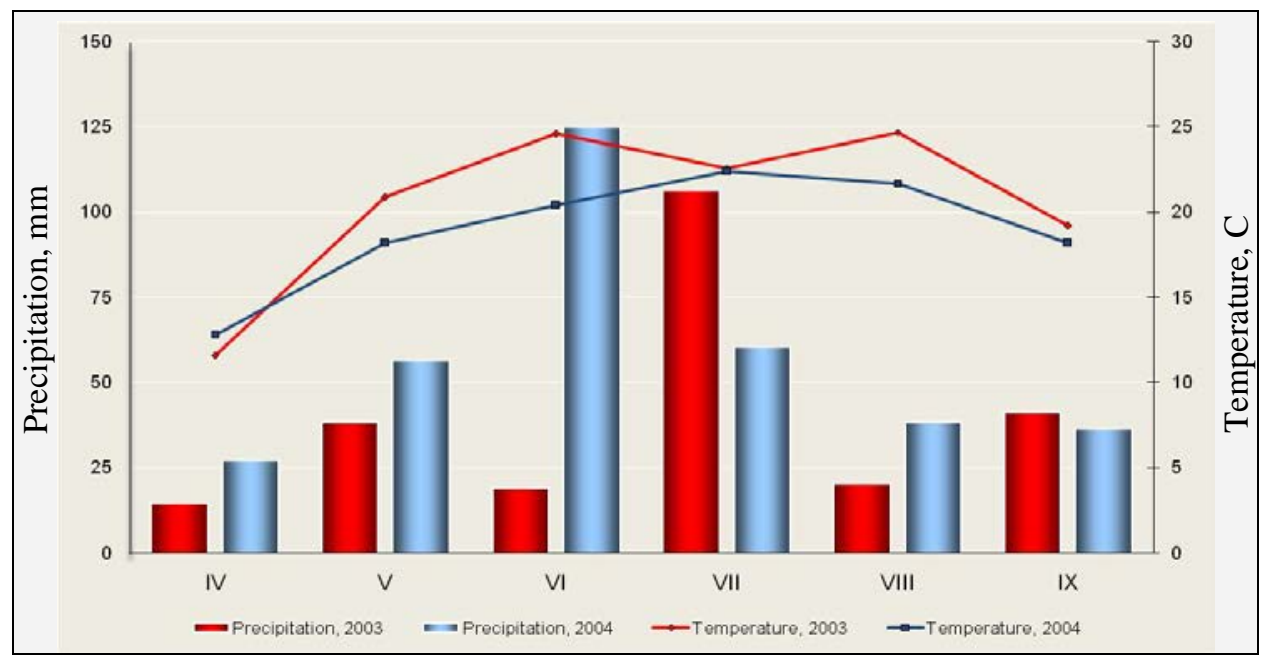

Figure 1. Precipitation and temperature, Zemun Polje, Serbia

In second year, the amount of precipitation during the vegetation period was at the level of perennial averages and about $105 \mathrm{~mm}$ higher compared to first year (Figure 1). 
The influence of the row spacing and genotype on the Net Photosynthesis Productivity (NAR)

The productivity of photosynthesis represents the increase in dry matter per unit area of the leaf surface in the unit of time (Kojić, 1987). Productivity of photosynthesis of one species does not have a constant value and, among other things, depends on external conditions (temperature, humidity, light intensity).

This parameter expresses the increase in dry weight. Therefore, this parameter was called pure or Net Photosynthesis Productivity (Popović, 1976; Haloi and Balden, 1986; Kojić, 1987; Kastori, 1989).

During the growing period of the genotypes encompassed by studies, NAR was uneven with different tendencies in both years of research (Tables 2 and 3).

Based on the research, we conclude that the productivity of photosynthesis of one species does not have a constant value, but depends on climatic conditions (temperature, humidity, etc.). Precipitation quantity during soybean growing period in first year was $240 \mathrm{~mm}$ and in second year was $350 \mathrm{~mm}$, Figure 1.

Table 2. Influence of row spacing and variety on the net assimilation in first year (NAR g/m² / day)

\begin{tabular}{|c|c|c|c|c|c|c|c|c|}
\hline \multirow{2}{*}{$\begin{array}{l}\text { Row } \\
\text { spacing } \\
\text { (A) }\end{array}$} & \multirow{2}{*}{$\begin{array}{c}\text { Variety } \\
\text { (B) }\end{array}$} & \multicolumn{7}{|c|}{ Interval } \\
\hline & & I-II & II-III & III-IV & IV-V & V-VI & $\begin{array}{l}\text { VI- } \\
\text { VII }\end{array}$ & $\begin{array}{l}\text { VII- } \\
\text { VIII }\end{array}$ \\
\hline 20 & \multirow{3}{*}{ Bosa } & 3.30 & 4.12 & 1.50 & 1.36 & 0.92 & & \\
\hline 45 & & 2.83 & 2.92 & 1.05 & 0.64 & 0.24 & - & \\
\hline 70 & & 2.72 & 2.51 & 0.98 & 0.18 & 0.16 & & - \\
\hline \multicolumn{2}{|c|}{ Average } & 2.95 & 3.18 & 1.18 & 0.73 & 0.44 & - & - \\
\hline 20 & \multirow{3}{*}{ Balkan } & 3.40 & 3.07 & 3.08 & 1.19 & 0.86 & 0.27 & \\
\hline 45 & & 2.73 & 2.91 & 2.91 & 1.20 & 0.45 & 0.16 & \\
\hline 70 & & 2.59 & 2.77 & 2.71 & 1.12 & 0.36 & 0.22 & - \\
\hline \multicolumn{2}{|c|}{ Average } & 2.91 & 2.92 & 2.90 & 1.17 & 0.56 & 0.22 & - \\
\hline 20 & \multirow{3}{*}{ Dragana } & 3.23 & 3.32 & 3.20 & 2.36 & 0.50 & 0.64 & 0.23 \\
\hline 45 & & 3.02 & 2.71 & 2.71 & 1.81 & 0.45 & 0.57 & 0.12 \\
\hline 70 & & 2.56 & 2.09 & 2.35 & 1.64 & 0.24 & 0.41 & 0.06 \\
\hline \multicolumn{2}{|c|}{ Average } & 2.94 & 2.71 & 2.75 & 1.94 & 0.40 & 0.54 & 0.14 \\
\hline \multirow{3}{*}{ Average } & 20 & 3.31 & 3.50 & 2.59 & 1.64 & 0.76 & 0.46 & 0.23 \\
\hline & 45 & 2.86 & 2.85 & 2.22 & 1.22 & 0.38 & 0.37 & 0.12 \\
\hline & 70 & 2.62 & 2.46 & 2.01 & 0.98 & 0.25 & 0.32 & 0.06 \\
\hline \multicolumn{2}{|c|}{ Total / Average } & 2.93 & 2.94 & 2.28 & 1.28 & 0.46 & 0.38 & 0.14 \\
\hline
\end{tabular}


In favorable second year, similar to first, the highest NAR values were in the first two measurement intervals (on average, 3.19 and $2.61 \mathrm{~g} / \mathrm{m}^{2} /$ day), Figure 2 and 3 . However, later, unlike the previous year, there is a steady decrease in the value of this parameter. The lowest values of this parameter were determined at the end of the vegetation period for the three investigated varieties. In both years, the highest NAR values were recorded by sowing in narrow rows.

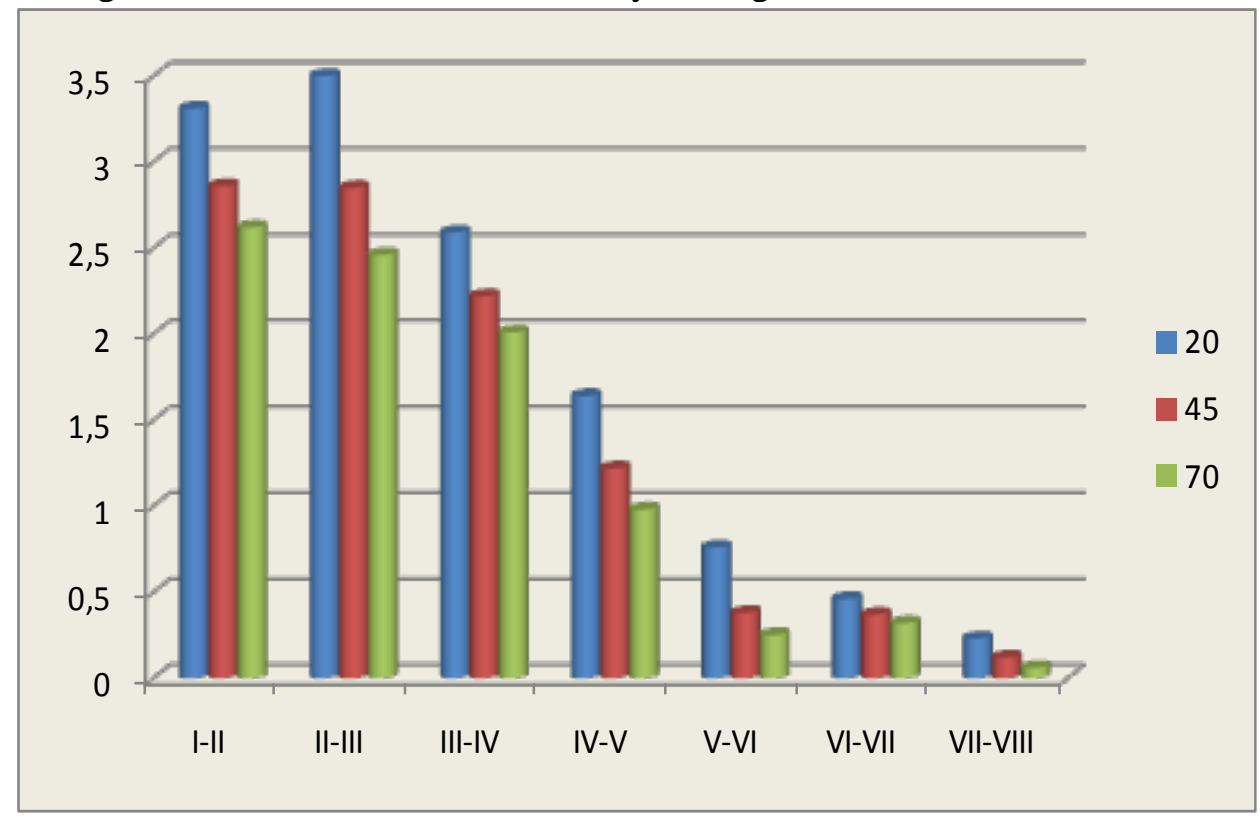

Figure 2. Influence of row spacing on the net assimilation the first year (NAR $\mathrm{g} / \mathrm{m}^{2} /$ day)

The variety of the longer vegetation period had a higher net assimilation compared to the earlier variety.

It is a derived parameter which has based on the leaf surface and a formed dry mass at a certain time and all the effects on them are also reflected on the NAR, similar to that of garlic (Castillo et al., 1996; Rizzali and Villalobos, 2002). The size of the leaf surface and its duration significantly influence the yield level (Kastori, 1989).

The highest NAR was observed at early stages of growth, 10-25 days after emergence, while in later stages it was decreased. The NAR is the most appropriate form of displaying the photosynthetic effect of plants and crops.

In a 14 soybean varieties research, Mitrović (1958) found that the leaf surface was in a positive correlation with the yield of the grain per unit area.

Hanway and Weber (1971) found that, in the flowering stage, the total dry weight of the plants is consisting of leaves (55\%), leafy stems (14\%) and stalk (31\%). The maximum dry matter of the leaf was obtained in the full blossoming phase. The maximum accumulation of total dry matter is achieved within 108 to 
115 days after sowing both, determinant or indeterminate type of soybean, according to Egli and Legget (1973).

Table 3. Influence of row spacing and variety on the net assimilation in second year (NAR g/ $\mathrm{m}^{2} /$ day)

\begin{tabular}{|c|c|c|c|c|c|c|c|c|c|}
\hline \multirow{2}{*}{$\begin{array}{c}\text { Row } \\
\text { spacing } \\
\text { (A) }\end{array}$} & \multirow{2}{*}{$\begin{array}{c}\text { Variety } \\
\text { (B) }\end{array}$} & \multicolumn{8}{|c|}{ Interval } \\
\hline & & I-II & II-III & III-IV & IV-V & $\mathrm{V}-\mathrm{VI}$ & $\begin{array}{l}\text { VI- } \\
\text { VII }\end{array}$ & $\begin{array}{l}\text { VII- } \\
\text { VIII }\end{array}$ & $\begin{array}{l}\text { VIII- } \\
\text { IX }\end{array}$ \\
\hline 20 & \multirow{3}{*}{ Bosa } & 3.70 & 3.41 & 2.20 & 2.03 & 1.24 & 0.96 & & \\
\hline 45 & & 2.85 & 2.49 & 2.16 & 1.81 & 0.88 & 0.71 & - & - \\
\hline 70 & & 2.59 & 1.85 & 1.94 & 1.68 & 0.72 & 0.29 & & \\
\hline \multicolumn{2}{|c|}{ Average } & 3.04 & 2.58 & 2.10 & 1.84 & 0.85 & 0.75 & - & - \\
\hline 20 & \multirow{3}{*}{ Balkan } & 3.10 & 3.10 & 2.53 & 1.50 & 1.47 & 1.35 & 1.16 & \\
\hline 45 & & 3.09 & 2.51 & 2.43 & 1.31 & 1.39 & 1.10 & 0.82 & - \\
\hline 70 & & 3.05 & 2.29 & 1.79 & 1.29 & 1.39 & 1.04 & 0.34 & \\
\hline \multicolumn{2}{|c|}{ Average } & 3.08 & 2.63 & 2.25 & 1.37 & 1.42 & 1.16 & 0.77 & - \\
\hline 20 & \multirow{3}{*}{ Dragana } & 3.89 & 2.97 & 2.30 & 1.93 & 0.93 & 1.23 & 1.04 & 0.91 \\
\hline 45 & & 3.85 & 2.89 & 1.97 & 1.43 & 0.79 & 1.07 & 0.81 & 0.57 \\
\hline 70 & & 2.58 & 1.97 & 1.82 & 1.29 & 0.70 & 0.88 & 0.79 & 0.17 \\
\hline \multicolumn{2}{|c|}{ Average } & 3.44 & 2.61 & 2.03 & 1.55 & 0.81 & 1.06 & 0.88 & 0.55 \\
\hline \multirow{3}{*}{ Average } & 20 & 3.56 & 3.16 & 2.34 & 1.82 & 1.21 & 1.18 & 1.10 & 0.91 \\
\hline & 45 & 3.26 & 2.63 & 2.19 & 1.52 & 1.02 & 0.96 & 0.82 & 0.57 \\
\hline & 70 & 2.74 & 2.04 & 1.85 & 1.42 & 0.94 & 0.74 & 0.57 & 0.17 \\
\hline \multicolumn{2}{|c|}{ Total / Averaqe } & 3.19 & 2.61 & 2.13 & 1.59 & 1.06 & 0.96 & 0.83 & 0.55 \\
\hline
\end{tabular}

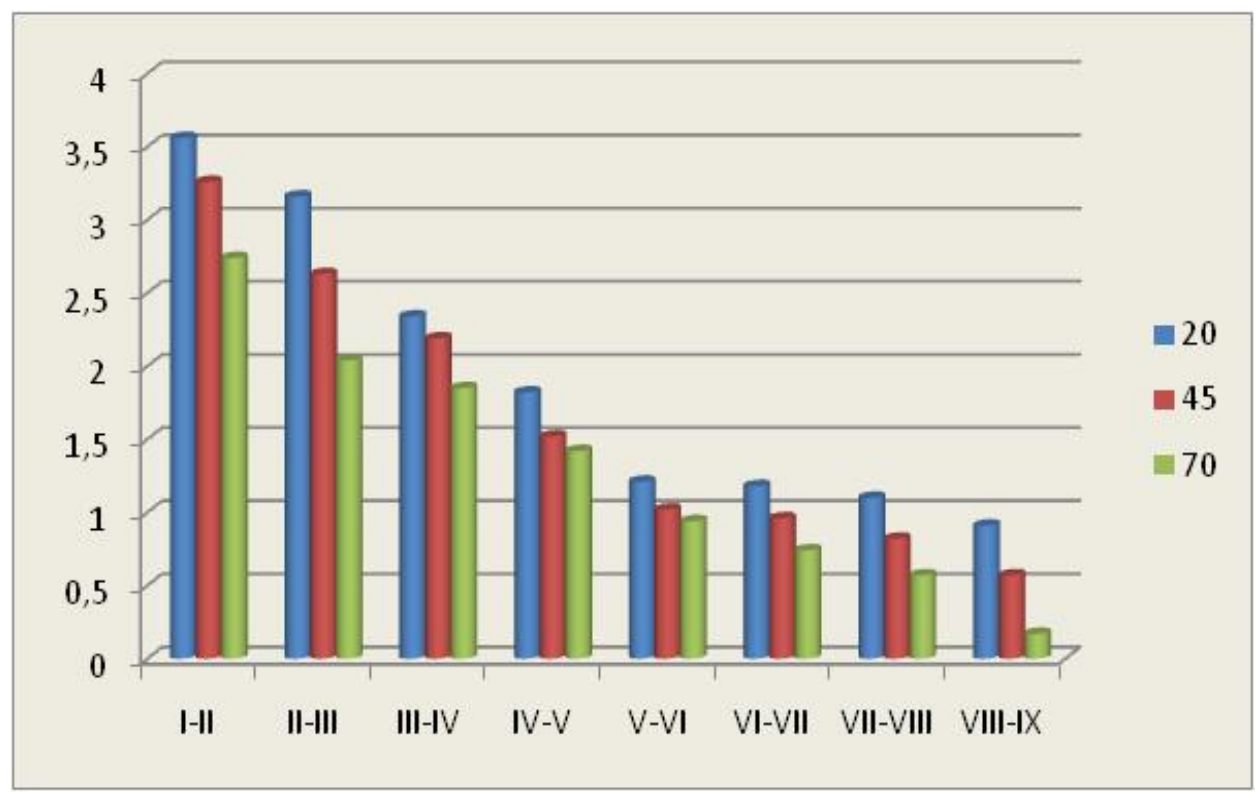

Figure 3. Influence of row spacing on the net assimilation in the second year (NAR $\mathrm{g} / \mathrm{m}^{2} /$ day) 
However, in terms of the accumulation of vegetative mass, the variety did not differ significantly, since its maximum weight was achieved approximately 89 days after sowing. After that, it fell because the leaves dying out were faster than the growth of new ones. The value of net assimilation varies depending on the genotype, Kolomejchenko (1982) points out.

It was established that high productive wheat genotypes $\left(7-9 t^{-1}\right)$ with the optimal architectonics possess higher rate of $\mathrm{CO}_{2}$ assimilation during the leaf ontogenesis. Along with the high rate of photosynthesis, high values of photorespiration are characteristic for the high productive genotypes. Genotypes with moderate (4-5 t ha ${ }^{-1}$ ) and low $\left(3 \mathrm{t} \mathrm{ha}^{-1}\right)$ grain yield are characterized by relatively low rates of both $\mathrm{CO}_{2}$ assimilation and photorespiration. A value of photorespiration constitutes 28-35\% of photosynthetic rate in contrasting genotypes (Aliyev, 2012).

Bunce (2014) was tested whether soybean photosynthesis at high light and elevated $\mathrm{CO}_{2}$ (ambient $+180 \mu \mathrm{mol} \mathrm{mol}{ }^{-1}$ ) was limited by electron transport $(J)$ in FACE systems but by ribulose-bisphosphate carboxylation capacity $\left(V_{\text {Cmax }}\right)$ in OTC. FACE systems with daytime and continuous $\mathrm{CO}_{2}$ enrichment were also compared. The results indicated that in both cultivars examined, midday photosynthesis at high light was always limited by $V_{\text {Cmax }}$, both in the FACE and in the OTC systems.

The correct selection of the interstitial spacing affects the aging of a higher biomass of soybean and therefore productivity (Kolarić et al., 2014).

Constant climate changes force legume, forage crops and mixtures to adapt to the altered conditions and require better efficiency of resource utilization by mixtures. At present, the main interest is directed towards more drought resistant and drought tolerant components. Legume species that can provide self - sowing and persist continuously in the sward become of practical importance (Vasileva et al., 2015).

Leguminous plants maintain a very privileged relationship with the rhizosphere. Their agronomic interest results first of all from their ability to establish a mutualistic symbiosis with bacteria belonging to Rhizobia family for the utilization of atmospheric nitrogen as a nitrogen source (Giri and Joshi, 2010). It is estimated that approximately 40-60 million metric tons of atmospheric nitrogen is fixed by cultivated legume plants annually (Mansouri and Kheloufi, 2013). Indeed, this symbiosis allows them to produce in abundance proteins even in the absence of nitrogenous fertilization. They play consequently a key role in the crop rotation (Popovic, 2010).

The use of biomass for bioenergy creates new business opportunities in agriculture sector. Bioenergy production can significantly contribute to the development of rural areas and encourage creating new supply chains for biomass feedstock. The creation of new non-food markets for biomass could provide alternative income sources for farmers (EC 2012) Agricultural residues, may act as important source of renewable energy. However, despite progress in 
these segments of crop production, the greatest potential for the use of biomass as fuel is seen in field (Čurović et al. 2016).

\section{CONCLUSIONS}

Based on the research, it can be concluded:

$>$ Sowing at different intermittent distances has affected the parameter net productivity of photosynthesis of soybean varieties of different lengths of the vegetation period.

$>$ The results show that the NAR increased until the fourth measurement, $\mathrm{R}_{4}$, at the varieties: Bosa and Balkan, and at the fifth measurement, $\mathrm{R}_{4}$, at variety Dragana when the seed formation phase $\left(R_{5}\right)$ was established.

$>\quad$ In the conditions of the arid and semi-arid climates, to whom northern parts of our country mostly belong, the advantage in the planting structure of the areas under the soybean should be given to medium-early varieties, with respect to the optimal sowing period (until April 10), and by this to try to avoid the adverse environmental conditions that were frequent in the summer months (June and July), especially in the last decade.

$>$ Significantly higher productivity of soybean photosynthesis can be achieved at smaller intervening distances $(20 \mathrm{~cm})$. In this way, a more favorable arrangement of plants, ie. shape of vegetation space is provided.

\section{ACKNOWLEDGMENTS}

This study was supported by the Ministry of Education, Science and Technological Development of the Republic of Serbia, and was created as a result of the projects: TR 31022 and TR 31078.

\section{REFERENCES}

Aliyev J.A. (2012): Photosynthesis, photorespiration and productivity of wheat and soybean genotypes. Physiol Plant. 145, 3: 369-83.

Bunce J.A. (2014): Limitations to soybean photosynthesis at elevated carbon dioxide in free-air enrichment and open top chamber systems. Plant Science. 226, 131-135.

Bozhanska T., Mihovski T., Naydenova G., Knotová D., Pelikán J. (2016): Comparative studies of annual legumes. Biotechnology in Animal Husbandry 32 (3): 311-320, DOI: 10.2298/BAH1603311B

Bullock D., Khan S., Rayburn A. (1998): Soybean yield response to narrow rows as largely due to to enchanced early growth. Crop Science, 38: 1011-1016.

Bowers R.,G., Rabb, L.J., Ashlok O.L, Santini, B. J (2000):. Row spacing in the early soybean production system. Agronomy Journal, 92: 524-531.

Castillo J.E., Lopez B.L., Fernandez E.J., Fuentes M., Lopez F.J. (1996): Influence of planting geometry on growth, yield and quality of rainfed garlic (Allium sativum L.) cultivated under Mediteranean conditions. Journal of Horticultural Science, 71, 6, 867-879.

Curovic, M., Pavicevic, K., Djokic, M., Drobnjak, D. (2016): Analysis of the energy potential of agricultural biomass residues in Montenegro. Agriculture and Forestry, 62 (3): 277-284.

Giri N. and Joshi NC. (2010): Growth and yield response of chick pea (Cicer arietinum) to seed inoculation with Rhizobium sp. Nature and Science, 8(9): 232-236. 
EC. (2012): Bio-economy strategy, innovating for sustainable growth: a bioeconomy for Europe. Brussels

Egli D.B., Legget, J.E. (1973): Dry matter accumulation patterns in determinate and indeterminate soybeans. Crop Science, Vol. 13, No 2. 555-565.

Haloi B., Balden B. (1986): Effect of irrigation on growth attributes in shickpea when grown under different dates of sowing and population pressure. Indian journal of Plant Physiology, 29, 14-27.

Hanway J.J., Weber C.R. (1971): Dry matter accumulation in light soybean. Agronomy Journal, Vol. 63, III-IV.

Heatherly L.G., Spurlock R.S, Elmor C. D. (2002): Row width and weed menagment system for early soybean production systems plantings in the midsouthern USA. Agronomy Journal, 94: 1172-1180.

Holshouser L.D., Whittaker P.J. (2002): Plant population and row spacing effects on early soybean production systems in the mid-atlantic USA. Agronomy Journal, 94: 603-611.

Kastori, R. (1989): Plant physiology. Matica Srpska, Novi Sad, 238-310.

Kojić, M. (1987): Phytological ecology of crop plants. Scientific book, Belgrade.

Kolarić LJ. (2010): Influence of intermittent spacing and variety on photosynthesis productivity, yield and quality of soybean. Master's thesis. University of Belgrade, Faculty of Agriculture, Zemun, 1-56.

Kolaric LJ., Zivanovic LJ., Popović V., Ikanović Jela, Srebric M. (2014a): Influence of inter-row spacing and cultivar on the productivity of soybean [Glycine max]. Biotechnology in Animal Husbandry 30,3: 517-528.

Kolaric LJ., Zivanovic LJ., Popović V., Ikanović J. (2014b): Influence of inter-row spacing and cultivar on the yield components of soybean [Glycine max (L.) Merr.]. Agriculture and Forestry, Podgorica, 60, 2, 167-176.

Kolarić LJ., Popović V., Paunović J., Živanović LJ., Ikanović J. (2015a): Sugar beet yield and quality in the agro-ecological conditions of central Banat, Serbia. Agriculture and Forestry. Podgorica, 61, 4: 33-41.

Kolarić, LJ., Gujaničić T., Zivanovic LJ., Ikanović J., Popović V. (2015b): The influence of cultivar and harvest date on Sugar beet yield and quality. Journal of Institute PKB Agroeconomic, Belgrade, 65-70.

Коломейченко В.В. (1982): Fotosintetičeskie osnovi povišenija produktivnosti kormovih kultur. Vestnik selskohozjastvenih nauk, No 7. 38-49.

Kresović B., Ikanović J., Rajić Z., Tapanarova A., Dražić G., Popović V. (2016): Canary Grass as a viable energy source and its future. Energetika-Energija, ekonomija, ekologija, 1-2, p. 141 - 155.

Mandić V., Bijelić Z., Krnjaja V., Tomić Z., Stanojković-Sebić A., Stanojković A., Petrović-Caro V. (2016): The effect of crop density on maize grain yield. Biotechnology in Animal Husbandry, 32, 1: 83-90.

Mansouri L. M., Kheloufi A. (2017): Effect of diluted seawater on seed germination and seedling growth of three leguminous crops (pea, chickpea and common bean), Agriculture and Forestry, 63 (2): 131-142. DOI: 10.17707/AgricultForest.63.1.11

Mitrović A. (1958): Influence of density and sowing method on morphological characteristics and yield of soybean in the southern Banat region. Archives for Agricultural Science, 11, 33, 44-54.

Nenadić N., Nedić M., Živanović LJ., Kolarić LJ., Simić A., Jovanović B., Vuković Z. (2003): The influence of vegetation space shape on the seed yield and fertility characteristics of soybean. Journal of Institute PKB Agroeconomic, Belgrade, 9, 1, 73-80. 
Popović M. Vera (2010): Influence of agro-technical and agro-ecological practices on seed production of wheat, maize and soybean. Doctoral Thesis, University of Belgrade, Faculty of Agriculture, Zemun Belgrade, Serbia, 55-66.

Popović V., Miladinović J., Malešević M., Marić V., Živanović LJ. (2013a): Effect of agroecological factors on variations in yield, protein and oil content in soybean grain. Romanian Agricultural Research, 30, 241-247.

Popović V., Miladinović J., Vidić M., Tatić M., Sikora V., Ikanović J., Dozet G. (2013b): Productive and quality characteristics of soybean in agro-ecological conditions of Sombor, Serbia. Field and Veg. Novi Sad, 50 (3), 67-74.

Popović V., Miladinović J., Vidić M., Vučković S., Dražić G., Ikanović J., Đekić V., Filipović V. (2015): Determining genetic potential and quality components of NS soybean cultivars under different agro-ecological conditions. Romanian Agricultural Research, No. 32, 35-42.

Popović V., Tatić M., Ikanović J., Dražić G., Đukić V., Mihailović B., Filipović V., Dozet G., Jovanović LJ. (2016a): Variability of yield and chemical composition in soybean genotypes grown under different agro-ecological conditions of Serbia. Romanian Agricultural Research, 33, 29-39.

Popović V., Vidić M., Ikanović J., Đekić, V., Filipović V., Tabaković M. (2016b): Soybean oil yield affected by the growing locality in agro-climatic divergent years. Agriculture and Forestry. 62, 1, 217-225.

Popović Ž. (1976): Plant Physiology. Scientific book, Belgrade, 206-216.

Petrović N. (1986): Practicum in plant physiology. IP Book, Belgrade.

Rizzalli R.H., Villalobos F.J. (2002): Radiation interception, radion utilization efficiency and dry matter partitioning in garlic (Allium sativum L.). European Journal of Agronomy, 18, 33-43.

Sarić M., Petrović M., Krstić B., Kastori R., Stanković Ž., Simić A., Vučković S. (2014): Pasture and meadow legumes in Serbia. Legume Perspectives, 5: 14-15.

Šarcević-Todosijević LJ., Živanović LJ., PopovićV., Ikanović J., Popović S., Drazić G. (2016): The influence of nitrogen fertilizer on the total number of microorganisms and aminoautotroph dynamics under 'Ugar' and sown maize. Agriculture and Forestry, 62 (3): 185-196.

Terzić D., Radović J., Marković J., Popović V., Milenković J., Vasić T., Filipović V. (2016): New technical-technological process of production voluminous animal feed by combining maize and soybean grown in double cropping. A new technical solution applied at the national level. Belgrade. Serbia. 1-40.

Terzić D., Popović V., Radović J., Marković J., Milenković J., Vasić T., Filipović V. (2017): The influence of combining crops and the method of sowing on the energy and protein value maize and soybean in the second sowing. Journal of Institute PKB Agroeconomic, Belgrade, 23, 1-2, 20-27.

Vasileva V., Vasilev E. (2012): Study on Productivity of some Legume Crops in Pure Cultivation and Mixtures. Agriculturae Conspectus Scientificus, 77 (2): 91-94.

Vasileva V., Kocheva K., Mincheva J., Georgiev G., Ilieva A., Porqueddu C. (2015): Nitrogen content in plant biomass from subterranean clover (Trifolium subterraneum L.) and cocksfoot (Dactylis glomerata L.) grown under different inorganic nitrogen supply. Ratar. Povrt. Novi Sad., 52, 3, 114-119.

Vignjević P. (2006): Morphological properties, quality and yield components depending on the shape of vegetation space in soybeans of different groups of ripening. Master's thesis, Faculty of Agriculture, Novi Sad. 